\title{
Phenolic profiles in apple leaves and the efficacy of selected phenols against fire blight (Erwinia amylovora)
}

\author{
Maria Skłodowska • Artur Mikiciński • \\ Marzena Wielanek • Elżbieta Kuźniak • \\ Piotr Sobiczewski
}

Accepted: 11 October 2017 / Published online: 2 November 2017

(C) The Author(s) 2017. This article is an open access publication

\begin{abstract}
The content and type of phenolic compounds in apple leaves as potential markers of resistance to fire blight were analysed. The amounts of phenolic acids and flavonoids were determined before and after E. amylovora inoculation of leaves of two cultivars: 'Enterprise' (highly resistant) and 'Idared' (highly susceptible). The basic levels of phenolics in both cultivars was similar but, following the inoculation, in the resistant one faster and more distinguishable changes were observed. The difference between the cultivars was related to the content of the compounds and the rate of release of free phenols from their glucosides. Regarding age dependency, the levels of eight out of 15 phenolics was significantly higher in young leaves of "Idared" than in 'Enterprise'. In the older leaves the differences were limited to four compounds. The amount of salicylic acid in 'Idared' was lower than in 'Enterprise'. In 'Idared' accumulation of salicylate after infection was better pronounced than in 'Enterprise'. Higher levels of naringenin glucosides, 4-hydroxbenzoic acid and gentisic acid were found in 'Enterprise'. The activity of 13 phenolics tested in vitro against the pathogen showed that gallic acid, phloroglucinol, hydroquinone
\end{abstract}

M. Skłodowska · M. Wielanek · E. Kuźniak

Department of Plant Physiology and Biochemistry, Faculty of

Biology and Environmental Protection, University of Łódź, 12/16

Banacha Str., 90-237 Łódź, Poland

A. Mikiciński · P. Sobiczewski $(\square)$

Research Institute of Horticulture, 18 Pomologiczna Str.,

96-100 Skierniewice, Poland

e-mail: piotr.sobiczewski@inhort.pl and phloretin, suppressed its growth. The aqueous solutions of gallic acid, phloroglucinol and hydroquinone also significantly limited the development of disease on pear fruitlet slices but only hydroquinone maintained its protective activity for longer time. It also showed very high efficacy in preventing disease spread on apple shoots. The study adds novel information on the contribution of specific phenolics to apple resistance to fire blight.

Keywords Malus domestica . Phenolic acids . Flavonoids · Apple resistance $\cdot$ Disease control

\section{Introduction}

Fire blight, caused by the bacterium Erwinia amylovora, belongs to the most dangerous diseases of Malus domestica and many other plant species, mainly from Rosaceae family. The pathogen attacks all organs of the aboveground parts of the host plant leading to their dieback. Common symptoms of fire blight are burntlike damages, often associated with bacterial ooze released from infected tissues. Young, vigorously growing plants are more susceptible than the older ones. Fire blight management is difficult and requires the integration of different approaches including planting of resistant and tolerant cultivars (Van der Zwet et al. 2012).

In similarity to other plant-pathogen interactions, the first line of host defense against fire blight is accompanied with oxidative burst, lipid peroxidation, shift in ion fluxes and induction of local reactions such as the 
hypersensitive response (HR) (Venisse et al. 2001; Iakimova et al. 2013). Accumulation of phytoalexins, activation of pathogenesis-related proteins and modification of plant hormone balance are often observed (Bonasera et al. 2006; Dugé de Bernonville et al. 2012; Van der Zwet et al. 2012). Following E. amylovora infection, in apple tree tissues, significant changes in secondary metabolite profiles, especially in the phenolic compounds pool are detected (Dao et al. 2011). These compounds, which generally fall into two categories i.e. phenolic acids and flavonoids, are involved in different physiological processes such as development, symbiosis, plant response to environmental stresses including pathogen invasion (Treutter 2005; Cheynier et al. 2013). Phenolics might be classified as phytoanticipins because they are constitutively synthesized in plants in anticipation of a pathogen attack (Cheynier et al. 2013).

Among the early events associated with plant reaction to pathogen attack is the rapid accumulation of phenolic compounds at the infection site eventually aimed at limiting the spread of the pathogen by isolating it at the primary entry point and by affecting biochemical processes that are vital for the bacterium (Iakimova et al. 2013). For example, some phenolic derivatives can react with pathogen proteins, causing loss of their enzymatic functions thus suppressing pathogen viability (Markakis et al. 2010). The flavonoids were described as having antibacterial, antitoxin, antiviral and/or antifungal activities and as being involved in structural defense (Treutter 2005). Characteristic for phenolics is that they express high antioxidant capacity due to which can play a role in cellular processes sensitive to redox effects. These compounds have an ability to influence the cell signaling by downregulating prooxidant enzymes, by altering the phosphorylation state of target molecules or by chelating transition metals involved in prooxidant processes (Treutter 2005; Hernández et al. 2009; Dugé de Bernonville et al. 2011).

The potential of the phenylpropanoid-flavonoid pathway to produce different end products is depended on the activities of enzymes such as reductases, oxygenases, ligases or transferases (Venisse et al. 2002; Gosch et al. 2010). The biosynthesis of phenolics is organ- and species-specific, proceeds in different rate and the spectrum of the compounds varies during the developmental stages (Treutter 2001). In response to pathogen infection, the synthesis of defense-related phenolics such as flavonoids, phenolamines, flavonoid phytoalexins, lignin and salicylic acid (SA) is enhanced (Treutter 2001; Venisse et al. 2002;
Fischer et al. 2007). Jensen et al. (2012) suggested that the phenylpropanoid pathway mobilization and activity might be one of the hallmarks of fire blight resistance. However, it should be taken into account that although the stimulation of this pathway is a part of plant resistance response, the processes are dependent also on pathogen activity; E. amylovora belongs to the pathogens which in order to overcome plant defense can delay the expression of phenylpropanoid genes (Venisse et al. 2002).

At pathogen attack phenolics contribute to signal transduction pathways involved in induced defense mechanisms (Treutter 2005). It is believed that SA plays an important regulatory role in the signaling cascade which orchestrates plant defense against pathogens (Dugé de Bernonville et al. 2012; Kumar 2014). E. amylovora-triggered activation of SA pathway is likely to be a feature of the interaction between this pathogen and apple (Milčevičová et al. 2010). It is suggested that during the stress response over $90 \%$ of SA is synthesized in plastids via chorismate synthase (Wildermuth et al. 2001). The SA molecules are quickly modified into different derivatives but most of them are glucosylated. SA glucoside is thought to be the main SA storage form. It may be quickly converted back to SA through an enzymatic reaction catalyzed by SA $\beta$-glucosidase (Kumar 2014).

The defense processes are regulated also by other hormones, including jasmonic acid (JA), abscisic acid and ethylene that operate in complicated crosstalk. In general, the defense pathways triggered by SA and JA are mutually antagonistic (Robert-Seilaniantz et al. 2007). Such relationship was shown in E. amylovora-Malus pathosystem. After infection of different apple cultivars with the bacterium, a significant accumulation of total SA was observed (Milčevičová et al. 2010; Dugé de Bernonville et al. 2012). In a susceptible apple cultivar JA was downregulated. Treatment of the susceptible plants with methyl jasmonate increased their resistance against $E$. amylovora. This indicated that the downregulation of JA pathway is a critical step in the infection process (Dugé de Bernonville et al. 2012). According to Iakimova et al. (2013) in E. amylovora-Malus pathosystem HR is mediated by ethylene and reactive oxygen species (ROS). Salicylic acid and gene-for-gene resistance are more typical for plant response to biotrophic pathogens, whereas JA and ethylene are involved mainly in interactions with necrotrophs (Glazebrook 2005). Speculatively, the participation of SA and JA in plant HR during the consecutive stages of invasion by E. amylovora may suggest that this pathogen can behave as hemi-necrotroph or necrotroph, as recently 
reported by Sobiczewski et al. (2016). In the various cases of pome fruit trees interaction with pathogens an increase or decrease of the levels of phenolic compounds is found (Venisse et al. 2002; Gosch et al. 2010). Taking into consideration the role of oxidative stress in HR and the antioxidant properties of phenolics, it might be suggested that by influencing the redox state they are able to modulate the course of HR (Glazebrook 2005). However, the exact function of phenolics in plant defense mechanisms in E. amylovora-pome fruit trees interaction is still not well understood. There are contradictory reports on the role of polyphenols in fire blight resistance. For example, Roemmelt et al. (1999) documented that apple with high phenolics content in the leaves are less susceptible to infection with E. amylovora whereas Dugé de Bernonville et al. (2011) did not find such trend in apple.

In the present work, we studied the profiles of soluble phenolic compounds, including SA, in the leaves from two $M$. domestica cultivars after inoculation with E. amylovora. The cultivars express different degree of resistance to fire blight (Sobiczewski et al. 2015). In relation to leaf age, the constitutive levels of the phenolic compounds were determined in intact plants of both cultivars. The possible antibacterial activity toward E. amylovora and phytotoxicity of selected phenolics were analyzed in vitro.

\section{Material and methods}

Plant material

The study was conducted with 1-year-old apple trees of two cultivars differing in susceptibility to fire blight: 'Enterprise' (highly resistant) and 'Idared' (highly susceptible). Trees were individually planted in pots with a mixture of soil and humus compost and grown in a greenhouse (temperature $20-26^{\circ} \mathrm{C}$, humidity $60-90 \%$ ).

Detached fruitlets of pear cv. Conference for laboratory tests were also used.

Preparation of E. amylovora inoculum and inoculation of apple leaves

The highly virulent strain Ea659 of E. amylovora from own collection was used for all inoculations. The strain was originally isolated in Poland from apple shoots and stored in the mixture of potassium phosphate buffer (PPB) and glycerol at $-75^{\circ} \mathrm{C}$. For inoculum preparation the bacteria were cultivated on NAS medium (2.3\% Difco Nutrient Agar with 5\% sucrose) at $26{ }^{\circ} \mathrm{C}$ and after $24 \mathrm{~h}$ washed out with sterile distilled water. The concentration of bacteria in the suspension was adjusted to $10^{7} \mathrm{CFU} \mathrm{ml}{ }^{-1}$ by measurement on spectrophotometer (Semco S91E) at $630 \mathrm{~nm}$ using serial dilutions and plating on NAS medium.

For analysis of the phenolic compounds content in inoculated leaves the fully developed leaves in the first and second position (young) from the terminal shoot tips and leaves from third and fourth position (older) (Fig. 1a) were inoculated by cutting across the leaf blade with scissors previously immersed in inoculum. The control included leaves similarly cut with scissors but immersed in sterile distilled water.

Extraction and analysis of phenolic compounds

For determination of the contents of phenolic compounds, the intact leaves from the first and second position as well as the third and fourth position from the terminal shoot tips were detached with petioles. After quick transfer to the laboratory $1 \mathrm{~g}$ samples were prepared as quickly as possible by cutting off fragments of leaf blade as shown on Fig. 1b, followed by their immediate freezing at $-20^{\circ} \mathrm{C}$ until analyses performance.

In a similar way the inoculated and/or injured leaves (control) at the same position were sampled from experimental trees 6, 24 and $72 \mathrm{~h}$ post-inoculation (hpi). The exception was analysis for SA which concentration was determined 24, 72 and 144 hpi.

Frozen leaf samples $(1 \mathrm{~g})$ were extracted twice with $15 \mathrm{ml}$ of $80 \%$ methanol. After centrifugation (15 min, $34,000 \times g)$ the supernatants were combined and evaporated to dryness under vacuum at $40{ }^{\circ} \mathrm{C}$. The residue was redissolved in hot water, centrifuged $(15 \mathrm{~min}, 2000 \times \mathrm{g})$ and filtered through a $22 \mu \mathrm{m}$ syringe filter (Millipore) before analysis. For chromatographic analysis HPLC system (DIONEX, Sunnyvale, CA, USA) equipped with a photodiode-array detector was used. Separation of the phenolic compounds was achieved on RP column (aQ Hypersil GOLD, $250 \times 4.6 \mathrm{~mm}, 5 \mu \mathrm{m}$, ThermoFisher Scientific) joined with a guard column (GOLD aQ DropIn guards, $10 \times 4 \mathrm{~mm}, 5 \mu \mathrm{m}$, ThermoFisher Scientific) at $25^{\circ} \mathrm{C}$ using a mobile phase composed of water and methanol, both with $0.1 \%$ formic acid. The linear gradient was started after $1 \mathrm{~min}$ of isocratic elution with $15 \%$ methanol and was slowly increased over $20 \mathrm{~min}$ to $55 \%$ methanol, followed by increase to $75 \%$ within $5 \mathrm{~min}$, and then after an isocratic step with $75 \%$ methanol for $1 \mathrm{~min}$ 


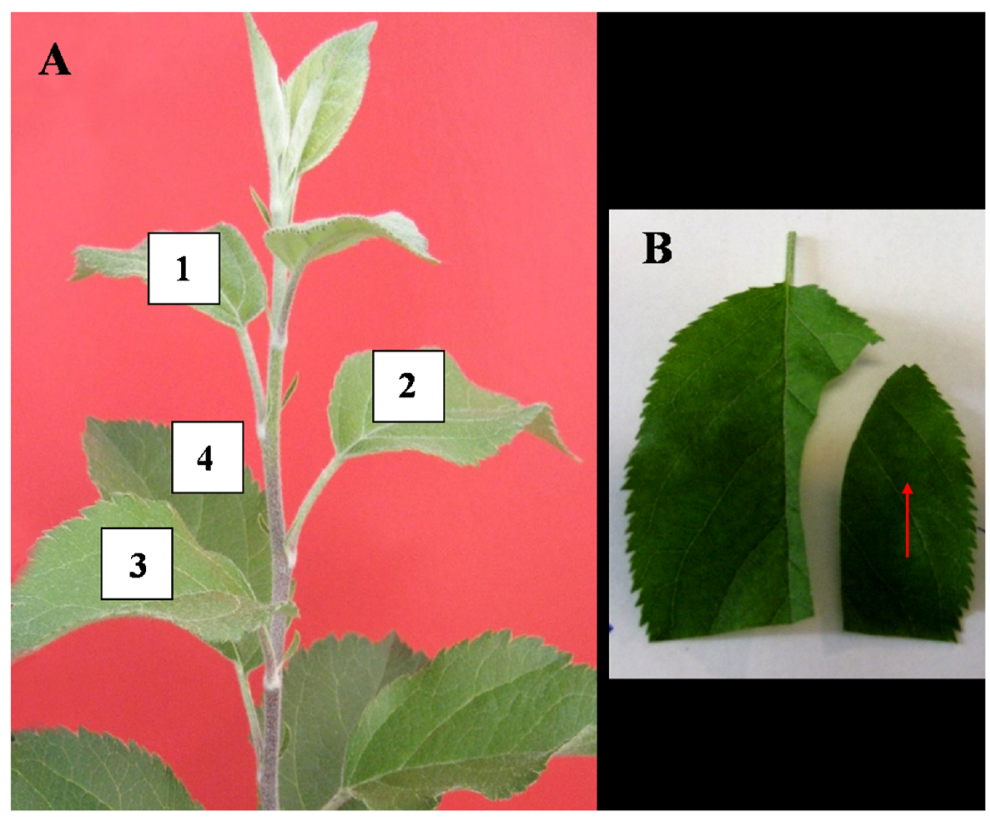

Notice: The profiles of phenols were analysed in the younger (position 1 and 2) and in the older (position 3 and 4) leaves of intact plants after infection with E. amylovora. A - positions of analysed leaves; B - an example of sampling leaf tissue for analysis (marked with arrow).

Fig. 1 The position of analysed leaves on apple shoots

the gradient was returned to initial $15 \%$ methanol within $1 \mathrm{~min}$ to re-equilibrate the column for the next $2 \mathrm{~min}$. The flow rate was $1 \mathrm{ml} \mathrm{min}^{-1}$ and the absorbance was measured at $260 \mathrm{~nm}$ (rutin), $280 \mathrm{~nm}$ (phloridzin, phloretin, $o$ cumaric acid) and $325 \mathrm{~nm}$ (chlorogenic acid). Peaks in chromatograms were identified by comparison with retention times of phenolic compound standards and by on-line UV absorption spectra; quantification was based on the calibration curves for standards.

Extraction and quantification of free and conjugated SA by HPLC were as described earlier (Skłodowska et al. 2011a). The total contents of phenolics and flavonoids were determined according to Singleton and Rossi (1965) and Chang et al. (2002), respectively. The results were given in the equivalents of chlorogenic acid (phenolics) and quercetin (flavonoids) per $1 \mathrm{~g} \mathrm{FW}$.

The influence of selected phenolic compounds on E. amylovora growth

The data obtained from the phenolics profile assay were used to select compounds for in vitro tests. The following aqueous and methanol solutions of phenols were tested in concentrations of 10,50 , and $100 \mathrm{mM}$ : caffeic acid, catechin, chlorogenic acid, p-coumaric acid, gallic acid, hesperidin, hydroquinone, 4-hydroxy-benzoic acid, phloretin, phloridzin, quercetin, rutin and phloroglucinol. The compounds were purchased from Sigma-Aldrich Co. To prepare aqueous solutions they were dissolved in a small volume of $80 \%$ methanol and after that distilled water was added ( $80 \%$ methanol/ distilled water 1:20 v/v). The methanol solutions were made in $80 \%$ methanol. To test the influence of mentioned phenolics on bacteria growth, the suspension of E. amylovora (Ea659) prepared as described above was uniformly distributed using glass rod on King B medium poured in Petri dishes. Then symmetrically disposed four wells $(\varnothing 10 \mathrm{~mm})$ using a cork borer were made in the medium. To three of the wells $150-200 \mu$ of the aqueous or methanol solution of the tested compound was added and to a fourth well the same amount of distilled water or methanol as a control was introduced. Each compound was tested in six replicates (2 Petri dishes $\times 3$ wells). The observations of $E$. amylovora growth around the wells was made after 24,48 and $72 \mathrm{~h}$ of incubation at $26^{\circ} \mathrm{C}$. The inhibition zones were measured and expressed as the width radius of zones measured from the edge of well. 
Evaluation of protective activity against fire blight of phloroglucinol, hydroquinone and gallic acid on pear fruitlets

Pear fruitlet slices of cv. Conference, at a thickness of 7$8 \mathrm{~mm}$ were momentarily dipped into the most active in vitro phenolics, namely aqueous solutions of phloroglucinol, hydroquinone and gallic acid (or distilled water as a control) and then placed in Petri dishes (Ø $20 \mathrm{~cm}$ ) on moist filter paper. The phenolics were used at concentration of $100 \mathrm{mM}$. After $6 \mathrm{~h}$ the slices were inoculated by spraying with a water suspension of Ea659 at a concentration of $10^{7} \mathrm{CFU} \mathrm{ml} \mathrm{m}^{-1}$, according to Sobiczewski and Millikan (1985) method. The disease symptoms were evaluated after 3, 5 and 7 days of incubation at room temperature. Each compound was tested on 40 slices $(4$ replications $\times 10)$. The following scale was applied to assess the disease severity: 0 - lack of visible symptoms of disease, 1 - appearance of the first bacterial ooze, 2 - single bacterial ooze covering $<50 \%$ of the slice area, 3 - bacterial ooze and necrosis covering $\geq 50 \%$ of the slice area, 4 - bacterial ooze and necrosis covering the whole slice.

Determination of protective activity against fire blight of phloroglucinol and hydroquinone on apple shoots

The tips of actively growing terminal shoots of 1year-old trees of cv. Idared grown in pots placed in the greenhouse were cut off with sterile scissors under the first undeveloped leaf and then were sprayed with 30,100 or $200 \mathrm{mM}$ of phloroglucinol or hydroquinone aqueous solutions. Inoculation was performed $4 \mathrm{~h}$ later by spraying the shoots with the suspension of Ea659

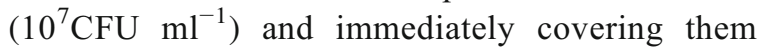
with plastic bags for $24 \mathrm{~h}$. The evaluation of the presence of fire blight symptoms was performed after 8 and 15 days. The disease severity was expressed as the percentage of necrosis in relation to the total shoot length. The standard copper oxychloride preparation (Miedzian 50WP, 50\% a.i.) as positive control was included to the study. Efficacy of the tested products was calculated on the basis of comparison of disease severity to distilled water treatment (negative control). Each combination was performed on 13 trees (together on 52 shoots).
Phytotoxicity of phloroglucinol and hydroquinone on apple blossoms

The blossoms on 1-year-old trees of cv. 'Idared' grown in pots placed in the greenhouse were sprayed with 10, 50, 100 or $200 \mathrm{mM}$ of aqueous solutions of phloroglucinol or hydroquinone. The control blossoms were sprayed with distilled water. After $24 \mathrm{~h}$, the occurrence of flower petals browning was recorded and expressed using the following scale: 0 - lack of changes, 1 - small changes covering $<10 \%$ of the flower petal area, 2 - changes covering $10 \%$ of the flower petal area, 3 - changes covering about $30 \%$ of the flower petal area, 4 - changes covering $50 \%$ of the flower petal area, 5 - changes covering $>50 \%$ of the flower petal area.

\section{Statistical analysis}

Sample variability is given as the standard deviation of the mean. The significance of differences between the control and the treated plants was determined by t-Student test, one-way ANOVA, and Newman-Keuls posthoc test. Differences at $p=0.05$ were considered significant. The normality of distribution and homoscedasticity were tested with Lilliefors and Brown-Forsythe methods, respectively. In cases of not observed of the above assumptions the transformation of results with Box-Cox was applied. All calculations were performed using STATISTICA software version 13.1 .

\section{Results}

Phenolic compounds in the leaves of apple plants

The HPLC analysis indicated that the amount of eight out of 15 phenolic compounds detected, was significantly higher in young leaves of "Idared" (highly susceptible) than in 'Enterprise' (highly resistant) (Table 1). Those higher amounts ranged from 24.7 and $73.2 \%$ in case of rutin and hydroquinone to 143.5 and $335.3 \%$ in case of chlorogenic acid and phloretin, respectively. The exception was SA the amount of which in the leaves of 'Idared' was lower by $33.7 \%$ than in 'Enterprise'.

In the older leaves the significant differences in the contents of phenolics were limited only to 4 compounds. Their amount was lower in 'Idared' than in 'Enterprise' leaves by: $39.1 \%$ in case of naringenin glucoside, $34.4 \%$ catechin, $49.2 \%$ - gentisic acid glucoside and $35.9 \%$ in 
Table 1 Selected phenolic compounds in the young $(\mathrm{Y})$ and older $(\mathrm{O})$ intact leaves of apple cultivars 'Enterprise' and 'Idared'

\begin{tabular}{|c|c|c|c|c|}
\hline Compound $\left(\mu \mathrm{g} \times \mathrm{g}^{-1} \mathrm{FW}\right)$ & Enterprise (Y) & Idared (Y) & Enterprise $(\mathrm{O})$ & Idared $(\mathrm{O})$ \\
\hline Phlorizin & $1314 \pm 208.0 \mathrm{a}$ & $2601 \pm 342.0 \mathrm{~b}[+98.0]^{\mathrm{a}}$ & $12,693 \pm 2869.0 \mathrm{a}$ & $11,610 \pm 1857.0 \mathrm{a}$ \\
\hline Phloretin & $7.54 \pm 4.1 \mathrm{a}$ & $32.82 \pm 12.7 \mathrm{~b}[+335.3]$ & $186.33 \pm 22.2 \mathrm{a}$ & $227.43 \pm 21.2 \mathrm{a}$ \\
\hline Rutin & $224.77 \pm 13.2 \mathrm{a}$ & $280.40 \pm 18.9 b[+24.7]$ & $142.85 \pm 17.4 \mathrm{a}$ & $145.74 \pm 7.1 \mathrm{a}$ \\
\hline Quercetin & $0.71 \pm 0.2 \mathrm{a}$ & $1.39 \pm 0.3 b[+95.8]$ & $1.92 \pm 0.8 \mathrm{a}$ & $1.76 \pm 0.5 \mathrm{a}$ \\
\hline Hesperidin & $9.07 \pm 3.7 \mathrm{a}$ & $14.84 \pm 5.6 \mathrm{a}$ & $18.49 \pm 7.9 \mathrm{a}$ & $24.34 \pm 8.1 \mathrm{a}$ \\
\hline Naringenin & ND & ND & $3.68 \pm 2.3 \mathrm{a}$ & $4.84 \pm 2.2 \mathrm{a}$ \\
\hline Naringenin glucoside & ND & ND & $58.71 \pm 16.3 b$ & $35.75 \pm 15.3$ a $[-39.1]$ \\
\hline Kaempferol & ND & ND & $4.53 \pm 2.4 \mathrm{a}$ & $3.14 \pm 0.7 \mathrm{a}$ \\
\hline Coumarin & $167.14 \pm 46.8 \mathrm{a}$ & $334.15 \pm 95.1 \mathrm{~b}[+100.0]$ & $825.67 \pm 98.0 \mathrm{a}$ & $898.80 \pm 203.8 \mathrm{a}$ \\
\hline Catechin & $7.67 \pm 2.2 \mathrm{a}$ & $17.64 \pm 3.2 \mathrm{~b}[+130.0]$ & $44.75 \pm 3.8 \mathrm{~b}$ & $29.34 \pm 4.2$ a $[-34.4]$ \\
\hline Catechin glucoside & ND & $\mathrm{ND}$ & $15.18 \pm 3.8 \mathrm{a}$ & $14.67 \pm 6.8 \mathrm{a}$ \\
\hline Hydroquinone & $65.71 \pm 19.2 \mathrm{a}$ & $113.79 \pm 31.2 b[+73.2]$ & $88.40 \pm 33.7 \mathrm{a}$ & $94.22 \pm 20.8 \mathrm{a}$ \\
\hline Chlorogenic acid & $6.39 \pm 2.4 \mathrm{a}$ & $15.56 \pm 3.17[+143.5]$ & $174.12 \pm 33.4 \mathrm{a}$ & $160.51 \pm 45.9 \mathrm{a}$ \\
\hline Caffeic acid & $1.44 \pm 0.9 \mathrm{a}$ & $2.28 \pm 1.1 \mathrm{a}$ & $6.62 \pm 2.0 \mathrm{a}$ & $6.13 \pm 0.7 \mathrm{a}$ \\
\hline$p$-coumaric acid & $1.49 \pm 0.3 \mathrm{a}$ & $1.44 \pm 0.5 \mathrm{a}$ & $4.91 \pm 1.5 \mathrm{a}$ & $4.64 \pm 1.3 \mathrm{a}$ \\
\hline Gentisic acid glucoside & $0.163 \pm 0.04 \mathrm{a}$ & $0.138 \pm 0.01 \mathrm{a}$ & $14.58 \pm 2.4 \mathrm{~b}$ & $7.40 \pm 1.2$ a $[-49.2]$ \\
\hline 4-hydroxy-benzoic acid glucoside & ND & ND & $9.65 \pm 1.3 \mathrm{~b}$ & $6.19 \pm 0.5$ a $[-35.9]$ \\
\hline Gallic acid & ND & ND & $1.48 \pm 0.8 \mathrm{a}$ & $1.86 \pm 0.9 \mathrm{a}$ \\
\hline Gallic acid glucoside & ND & $\mathrm{ND}$ & $70.23 \pm 18.5 \mathrm{a}$ & $84.70 \pm 17.9 \mathrm{a}$ \\
\hline Salicylic acid & $0.255 \pm 0.04 \mathrm{~b}$ & $0.169 \pm 0.03$ a $[-33.7]$ & $0.246 \pm 0.06 \mathrm{a}$ & $0.194 \pm 0.05 \mathrm{a}$ \\
\hline Total flavonoids & $4028 \pm 498.0 \mathrm{a}$ & $4748 \pm 475.0 \mathrm{a}$ & $4424 \pm 618.0 \mathrm{a}$ & $4536 \pm 372.0 \mathrm{a}$ \\
\hline Total phenols & $2421 \pm 196.0 \mathrm{a}$ & $2607 \pm 213.0 \mathrm{a}$ & $3815 \pm 261.0 \mathrm{a}$ & $3225 \pm 401.0 \mathrm{a}$ \\
\hline
\end{tabular}

a in brackets \% of increase or decrease in comparison to 'Enterprise'; values represent means and \pm SD from six replications; analysis consisted data of the individual phenolic compounds detected in both cultivars, separately for young and older leaves; mean values with the same letter do not differ significantly according to t-Test $(p=0.05)$, ND not detected

case of 4-hydroxy-benzoic acid glucoside. In the younger and older leaves of both cultivars phloridzin and chlorogenic acid contents dominated among flavonoids and phenolic acids, respectively, but the levels of total flavonoids and total phenolic acids were similar (Table 1).

Phenolic compounds profiles in young leaves of 'Enterprise' and 'Idared' after E. amylovora inoculation

In 'Idared' leaves, shortly after inoculation (6 hpi) significant increases in naringenin glucoside and catechin glucoside levels were observed, respectively by 72.9 and $48.2 \%$ of the respective control (water) values (Table 2). Phloretin, catechin and $p$-coumaric acid showed decrease by $42.6,29.7$ and $39.5 \%$, respectively, in comparison to the control. Twenty four hpi phloretin level constituted $46.6 \%$ of the control value. At this time only the amount of chlorogenic acid increased by $60.9 \% \%$ over the control. After $72 \mathrm{~h}$ the levels of hesperidin and gentisic acid glucoside decreased by 58.9 and $37.6 \% \%$ of the respective control values but those of catechin glucoside and gallic acid increased by 56.9 and $212.1 \%$, respectively in comparison to control. In the case of examined glucosides, their decreased levels did not correlate with the changes in respective free phenolics.

E. amylovora inoculation induced more pronounced changes in the leaves of 'Enterprise' than of 'Idared'. Six hpi the levels of the several substances were significantly higher than their respective control (water) values: in case of: naringenin by $209 \%$, chlorogenic acid $-114.2 \%$, caffeic acid $-34.8 \%$ p-coumaric acid $-62.3 \%$, gentisic acid glucoside - 79.3\%, 4-hydroxybenzoic acid glucoside $-104.8 \% \%$ and gallic acid by $94.5 \%$ (Table 3). Interestingly, the levels of catechin glucoside and gallic acid glucoside decreased by 52.4 and $23.4 \%$ in comparison to 


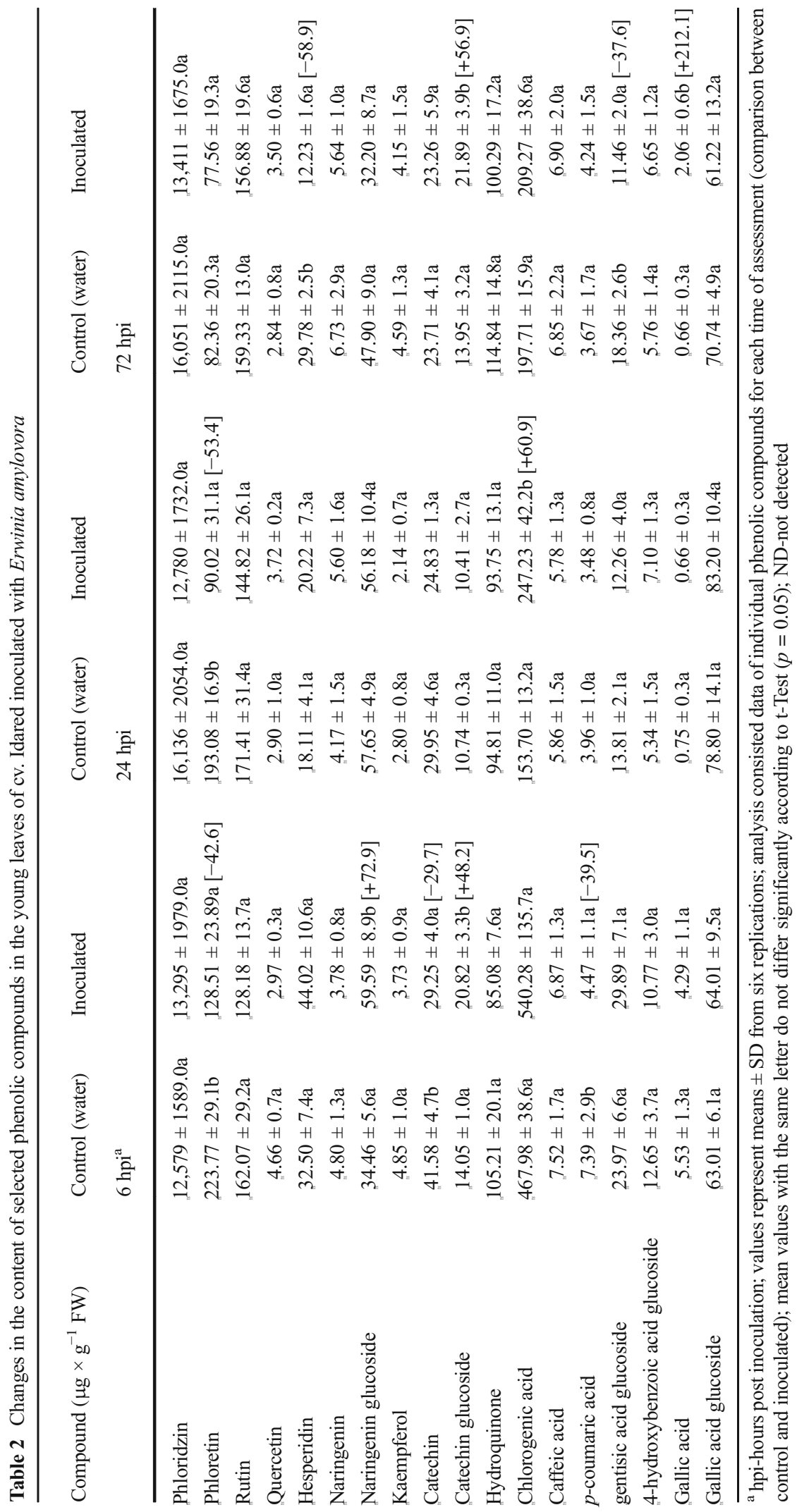




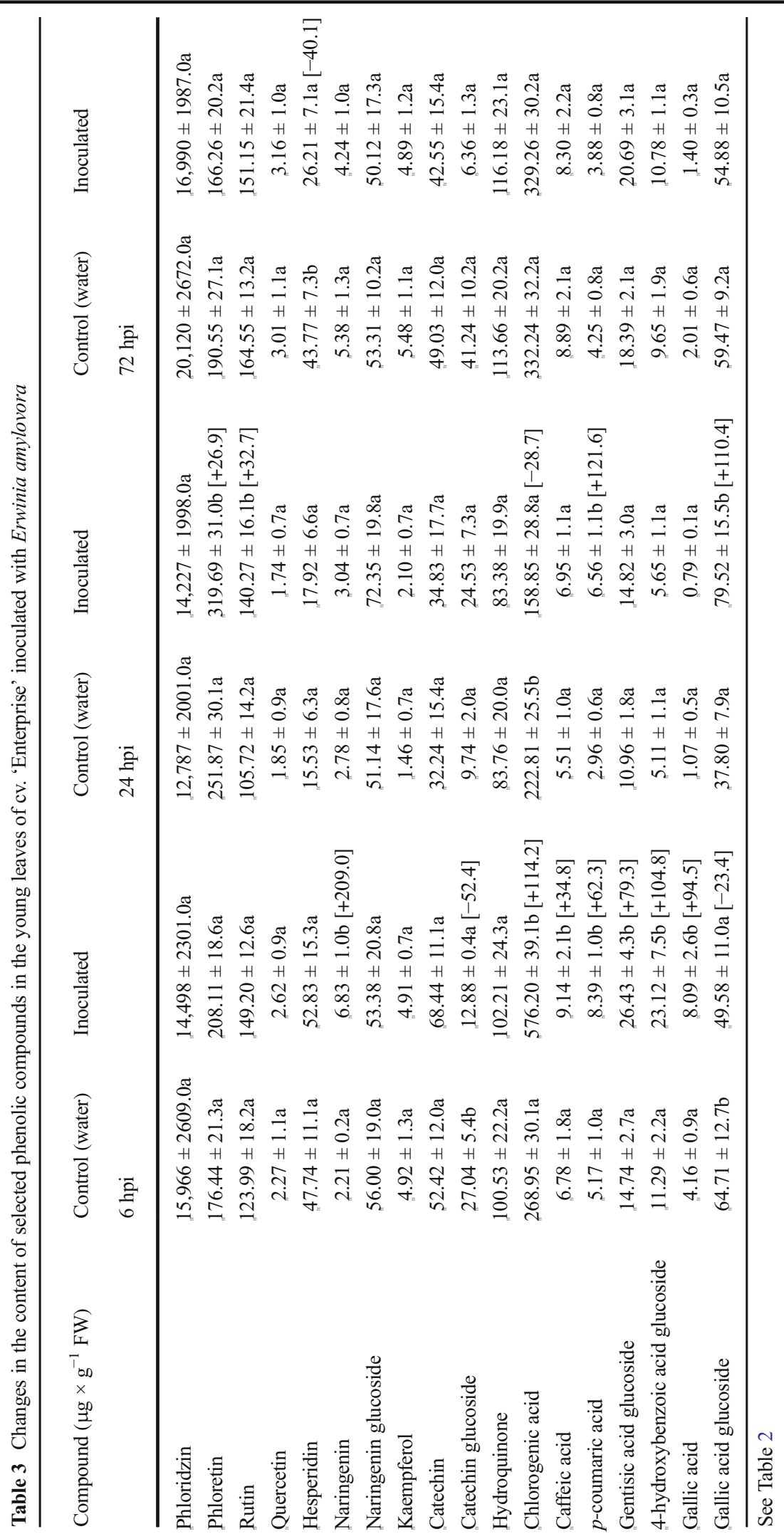


respective controls. Twenty four hpi the concentration of $p$ acid was still significantly higher than the control (increase by $121.6 \%$ ). The amount of phloretin, rutin, and gallic acid glucoside also increased respectively by $26.9,32.7$ and $110.4 \%$. However, the level of chlorogenic acid decreased to $71.3 \%$ of the control value. Two days later ( $72 \mathrm{hpi}$ ) only the concentration of hesperidin dropped significantly to about $60 \%$ of its respective control value.

Salicylic acid content in E. amylovora inoculated apple leaves

Analysis performed 24, 72 and 144 hpi showed that total amounts of SA conjugates (gSA) were significantly higher in the inoculated and control leaves of both cultivars than those of free SA (Fig. 2). After inoculation, the level of gSA in "Idared" leaves increased throughout the experiment whereas in 'Enterprise' this effect was observed only 24 and 144 hpi. At 72 hpi the content of gSA was about $60 \%$ lower than in the control. At 24 hpi the amount of gSA was about $30 \%$ higher in inoculated leaves of 'Idared' than in 'Enterprise' but at $144 \mathrm{hpi}$ an inverse ratio was found. The concentration of free SA measured at 24 and $144 \mathrm{hpi}$, both in inoculated and control leaves, was higher in 'Enterprise' than in 'Idared' but at 72 hpi no changes between cultivars were observed. However, when the inoculated and control leaves were compared, in 'Enterprise' the level of free SA did not differ significantly whereas in 'Idared' at 72 and 144 hpi it was higher in the inoculated leaves.

Activity of the selected phenolic compounds in limiting E. amylovora growth in vitro

The observations showed that from the tested phenolics the activity against pathogen was clearly demonstrated only for gallic acid, phloroglucinol, hydroquinone and phloretin. Measurements made after $24 \mathrm{~h}$ of incubation indicated that gallic acid (50 and $100 \mathrm{mM}$ ) and phloroglucinol $(100 \mathrm{mM})$, both methanol and aqueous solutions, appeared to be most effective (Table 4). Slightly lower efficacy showed methanol solutions of hydroquinone and phloretin applied at all concentrations and phloroglucinol at $50 \mathrm{mM}$. Similar activity expressed also aqueous solutions of hydroquinone at $100 \mathrm{mM}$ and phloroglucinol at $50 \mathrm{mM}$ while lack of activity was

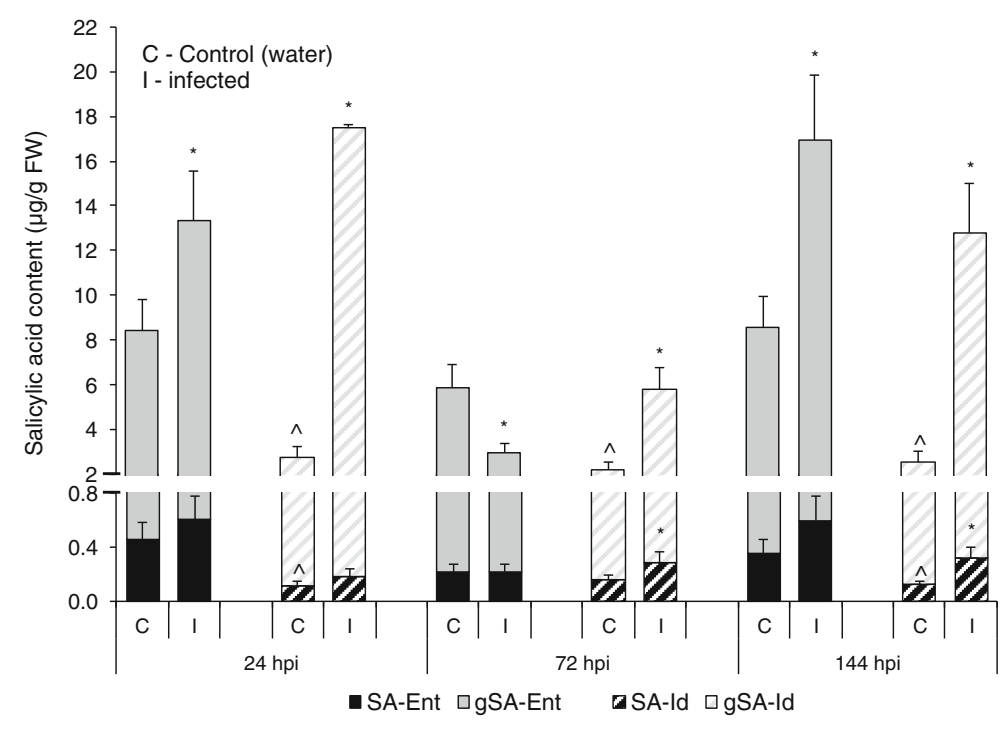

Notice: Contents of free salycilic acid (SA) and its conjugates (SA-Ent, gSA-Ent) with glucose, in 'Enterprise' leaves; contents of free SA and its conjugates (SA-Id, gSA-Id) with glucose, in 'Idared' leaves. Values represent means \pm SD from three replications $(n=3)$; $*$ indicates significant differences in leaves between the inoculated and control plants 'Enterprise' and 'Idared', respectively $(\mathrm{p}=0.05)$; $^{\wedge}$ indicates significant differences between control plants 'Enterprise' and 'Idared', according to t-Test ( $\mathrm{p}=0.05)$.

Fig. 2 Changes in the salicylic acid pool in leaves of the tolerant 'Enterprise' and susceptible 'Idared' apple cultivars infected with E. amylovora 
Table 4 Growth inhibition zones (mm) of Erwinia amylovora caused by selected phenolic compounds

Treatment

Solution

Concentration

$(\mathrm{mM})$

\begin{tabular}{|c|c|c|c|c|c|}
\hline & & \multirow{2}{*}{$(\mathrm{mM})$} & \\
\hline & & & $24 \mathrm{~h}$ & $48 \mathrm{~h}$ & $72 \mathrm{~h}$ \\
\hline \multicolumn{3}{|l|}{ Control (water) } & $0.0 \pm 0.0 \mathrm{ab}$ & $0.0 \pm 0.0 \mathrm{a}$ & $0.0 \pm 0.0 \mathrm{a}$ \\
\hline \multicolumn{3}{|l|}{ Control (methanol) } & $0.0 \pm 0.0 \mathrm{ab}$ & $0.0 \pm 0.0 \mathrm{a}$ & $0.0 \pm 0.0 \mathrm{a}$ \\
\hline \multirow[t]{6}{*}{ Gallic acid } & \multirow[t]{3}{*}{ Aqueous } & 10 & $1.8 \pm 0.8 \mathrm{e}$ & $1.0 \pm 0.0 \mathrm{~b}$ & $0.5 \pm 0.0 \mathrm{~b}$ \\
\hline & & 50 & $6.3 \pm 0.6 \mathrm{k}$ & $3.0 \pm 0.0 \mathrm{def}$ & $3.0 \pm 0.0 \mathrm{~h}$ \\
\hline & & 100 & $8.8 \pm 0.81$ & $4.7 \pm 0.3 \mathrm{~g}$ & $2.7 \pm 0.3 \mathrm{~g}$ \\
\hline & \multirow[t]{3}{*}{ Methanolic } & 10 & $1.0 \pm 0.0 \mathrm{~cd}$ & $1.0 \pm 0.0 \mathrm{~b}$ & $1.0 \pm 0.0 \mathrm{c}$ \\
\hline & & 50 & $5.2 \pm 0.3 \mathrm{j}$ & $1.8 \pm 0.3 \mathrm{c}$ & $1.8 \pm 0.3 \mathrm{e}$ \\
\hline & & 100 & $7.2 \pm 0.3 \mathrm{k}$ & $3.3 \pm 0.6 \mathrm{f}$ & $3.0 \pm 0.0 \mathrm{hi}$ \\
\hline \multirow[t]{6}{*}{ Phloroglucinol } & \multirow[t]{3}{*}{ Aqueous } & 10 & $0.0 \pm 0.0 \mathrm{a}$ & $0.0 \pm 0.0 \mathrm{a}$ & $0.0 \pm 0.0 \mathrm{a}$ \\
\hline & & 50 & $2.37 \pm 0.6 \mathrm{e}-\mathrm{h}$ & $1.0 \pm 0.0 \mathrm{~b}$ & $0.0 \pm 0.0 \mathrm{a}$ \\
\hline & & 100 & $5.0 \pm 0.0 \mathrm{j}$ & $3.0 \pm 0.0 \mathrm{ef}$ & $3.0 \pm 0.0 \mathrm{~h}$ \\
\hline & \multirow[t]{3}{*}{ Methanolic } & 10 & $0.5 \pm 0.5 b c$ & $1.0 \pm 0.0 \mathrm{~b}$ & $1.0 \pm 0.0 \mathrm{c}$ \\
\hline & & 50 & $2.2 \pm 0.3 \mathrm{efg}$ & $1.2 \pm 0.3 b$ & $1.2 \pm 0.3 \mathrm{c}$ \\
\hline & & 100 & $3.8 \pm 0.8 \mathrm{i}$ & $2.8 \pm 0.8 \mathrm{def}$ & $3.0 \pm 0.0 \mathrm{~h}$ \\
\hline \multirow[t]{6}{*}{ Hydroquinone } & \multirow[t]{3}{*}{ Aqueous } & 10 & $1.0 \pm 0.0 \mathrm{~d}$ & $1.0 \pm 0.0 \mathrm{~b}$ & $0.0 \pm 0.0 \mathrm{a}$ \\
\hline & & 50 & $1.0 \pm 0.0 \mathrm{~d}$ & $1.0 \pm 0.0 \mathrm{~b}$ & $0.0 \pm 0.0 \mathrm{a}$ \\
\hline & & 100 & $2.0 \pm 0.0 \mathrm{ef}$ & $2.0 \pm 0.0 \mathrm{c}$ & $1.0 \pm 0.0 \mathrm{c}$ \\
\hline & \multirow[t]{3}{*}{ Methanolic } & 10 & $2.3 \pm 0.6 \mathrm{e}-\mathrm{h}$ & $2.0 \pm 0.0 \mathrm{c}$ & $1.0 \pm 0.0 \mathrm{c}$ \\
\hline & & 50 & $2.5 \pm 0.0 \mathrm{e}-\mathrm{h}$ & $2.5 \pm 0.0 \mathrm{~d}$ & $1.5 \pm 0.0 \mathrm{~d}$ \\
\hline & & 100 & $3.0 \pm 0.0 \mathrm{gh}$ & $3.0 \pm 0.0 \mathrm{def}$ & $2.2 \pm 0.3 \mathrm{f}$ \\
\hline \multirow[t]{6}{*}{ Phloretin } & \multirow[t]{3}{*}{ Aqueous } & 10 & $0.0 \pm 0.0 \mathrm{ab}$ & $0.0 \pm 0.0 \mathrm{a}$ & $0.0 \pm 0.0 \mathrm{a}$ \\
\hline & & 50 & $0.0 \pm 0.0 \mathrm{a}$ & $0.0 \pm 0.0 \mathrm{a}$ & $0.0 \pm 0.0 \mathrm{a}$ \\
\hline & & 100 & $0.0 \pm 0.0 \mathrm{a}$ & $0.0 \pm 0.0 \mathrm{a}$ & $0.0 \pm 0.0 \mathrm{a}$ \\
\hline & \multirow[t]{3}{*}{ Methanolic } & 10 & $3.0 \pm 0.0 \mathrm{ghi}$ & $2.7 \pm 0.3 \mathrm{de}$ & $2.7 \pm 0.3 \mathrm{~g}$ \\
\hline & & 50 & $2.8 \pm 0.3 \mathrm{fgh}$ & $3.0 \pm 0.0 \mathrm{def}$ & $3.0 \pm 0.0 \mathrm{gh}$ \\
\hline & & 100 & $3.2 \pm 0.3 \mathrm{~h}$ & $3.2 \pm 0.3 \mathrm{ef}$ & $3.0 \pm 0.0 \mathrm{gh}$ \\
\hline
\end{tabular}

Values represent means and SD from six replications; mean values with the same letter in each column do not differ significantly according to Newman-Keuls test $(p=0.05)$

found for the aqueous solutions of phloretin. Observations made after $72 \mathrm{~h}$ of incubation revealed the longest activity of $100 \mathrm{mM}$ aqueous and methanol solutions of gallic acid and phloroglucinol as well as methanol solutions of phloretin at all applied concentrations.

In general, after 24 and $48 \mathrm{~h}$ of incubation methanol solutions of hydroquinone and phloretin were more active than those of aqueous solutions but in case of gallic acid and phloroglucinol inverse results were obtained. However, in comparison to methanol solutions aqueous solutions lost their activity more quickly. It should be noted that methanol solutions were also more persistent. In general, the best inhibitory activity was observed for gallic acid (Table 4).

Efficacy of the selected phenolic compounds in protection of pear fruitlets

Aqueous solutions of gallic acid, phloroglucinol and hydroquinone at $100 \mathrm{mM}$ significantly limited development of fire blight on pear fruitlet slices during first 3 days after inoculation (Table 5). Their efficacy ranged from 75 to $90 \%$. However, evaluation made 2 and 4 days later showed that only hydroquinone sustained its protective activity and its efficacy amounted 65.6 and $46.1 \%$ respectively. 
Table 5 Efficacy of phloroglucinol, hydroquinone and gallic acid, applied in $100 \mathrm{mM}$ aqueous solution, in protection of pear fruitlet slices against $E$ amylovora infection

Treatment Degree of fire blight severity

\begin{tabular}{llll}
\cline { 2 - 3 } & 3 dpi & 5 dpi & 7 dpi \\
\hline Control $^{\mathrm{b}}$ & $1.0 \pm 0.2 \mathrm{~b}$ & $2.47 \pm 0.5 \mathrm{~b}$ & $3.62 \pm 0.3 \mathrm{~b}$ \\
Phloroglucinol & $0.2 \pm 0.1 \mathrm{a}[80.0]^{\mathrm{c}}$ & $1.75 \pm 0.4 \mathrm{~b}[29.1]$ & $3.5 \pm 0.0 \mathrm{~b}[3.3]$ \\
Hydroquinone & $0.1 \pm 0.1 \mathrm{a}[90.0]$ & $0.85 \pm 0.4 \mathrm{a}[65.6]$ & $1.95 \pm 0.4 \mathrm{a}[46.1]$ \\
Gallic acid & $0.25 \pm 0.1 \mathrm{a}[75.0]$ & $2.15 \pm 0.6 \mathrm{~b}[13.0]$ & $3.32 \pm 0.6 \mathrm{~b}[8.3]$ \\
\hline
\end{tabular}

dpi days post inoculation

${ }^{a}$ Scale: 0-lack of visible symptoms; 4-bacterial oozes and necrosis of whole slices

b Control (distilled water)

c The efficacy (degree of fire blight severity in relation to the control) in percent given in brackets

Values represent means and SD from 4 independent replications. Mean values with the same letter in each columns do not differ significantly according to Newman-Keuls test $(p=0.05)$

Efficacy of the selected phenolic compounds in protection of apple shoots

Phloroglucinol and hydroquinone applied $4 \mathrm{~h}$ prior to E. amylovora inoculation significantly limited the fire blight development on 'Idared' shoots. However, the activity of both compounds was related to their concentration. Eight days post-inoculation (dpi) hydroquinone applied in 100 and $200 \mathrm{mM}$ demonstrated the highest efficacy (up to $89.4 \%$ ) as compared to phloroglucinol and copper preparation (Miedzian 50 WP) (Table 6). Severity of fire blight on shoots did not differ significantly after application of $30 \mathrm{mM}$ hydroquinone as well as 100 and $200 \mathrm{mM}$ phloroglucinol. The efficacy of these compounds was 40.0, 29.2 and 30.3\%, respectively. Phloroglucinol applied at the lowest concentration $(30 \mathrm{mM})$ did not reduce the fire blight symptoms on the shoots (Table 6). Fifteen dai, hydroquinone used in concentrations of 100 and $200 \mathrm{mM}$ showed the highest efficacy 88.7 and $87.7 \%$, respectively. At $30 \mathrm{mM}$ it was less effective (44.4\%) and did not differ from phloroglucinol which demonstrated low protective activity. Its effectiveness ranged from about 22.3 to $29.7 \%$, depending on the concentration.

Phytotoxic effect of phloroglucinol and hydroquinone on apple blossoms

In general, hydroquinone was more phytotoxic than phloroglucinol (Table 7). Applied in concentrations of 100 and $200 \mathrm{mM}$ it caused browning of flower petals at highest degree. Almost no negative effect was found when the blossoms were sprayed with 10 and $50 \mathrm{mM}$ phloroglucinol. When used at higher concentrations this compound appeared only slightly toxic.

Table 6 Efficacy of phloroglucinol and hydroquinone in protection of 'Idared' apple terminal shoots against fire blight

\begin{tabular}{|c|c|c|}
\hline \multirow[t]{3}{*}{ Treatment } & \multicolumn{2}{|c|}{$\begin{array}{l}\text { Percentage of shoot necrosis in } \\
\text { comparison to the total length of shoots }\end{array}$} \\
\hline & \multicolumn{2}{|c|}{ Days post inoculation } \\
\hline & 8 & 15 \\
\hline Control $^{\mathrm{a}}$ & $43.5 \pm 2.2 \mathrm{~d}$ & $74.1 \pm 9.6 \mathrm{~d}$ \\
\hline \multicolumn{3}{|l|}{ Phloroglucinol } \\
\hline $30 \mathrm{mM}$ & $43.0 \pm 3.3 \mathrm{~d}[0]^{\mathrm{b}}$ & $56.5 \pm 2.0 \mathrm{c}[23.7]$ \\
\hline $100 \mathrm{mM}$ & $30.8 \pm 1.8 \mathrm{c}[29.2]$ & $57.6 \pm 3.5 \mathrm{c}[22.3]$ \\
\hline $200 \mathrm{mM}$ & $30.3 \pm 4.9 \mathrm{c}[30.3]$ & $52.1 \pm 5.9 \mathrm{c}[29.7]$ \\
\hline \multicolumn{3}{|l|}{ Hydroquinone } \\
\hline $30 \mathrm{mM}$ & $26.1 \pm 4.4 \mathrm{c}[40.0]$ & $41.2 \pm 9.1 \mathrm{bc}[44.4]$ \\
\hline $100 \mathrm{mM}$ & $4.6 \pm 3.3 \mathrm{a}[89.4]$ & $8.4 \pm 6.6 \mathrm{a}[88.7]$ \\
\hline $200 \mathrm{mM}$ & $4.6 \pm 1.6 \mathrm{a}[89.4]$ & $9.1 \pm 2.4 \mathrm{a}[87.7]$ \\
\hline Miedzian 50 WP $0.75 \%^{\mathrm{c}}$ & $13.5 \pm 5.1 \mathrm{~b}[69.0]$ & $31.9 \pm 6.6 b[56.9]$ \\
\hline
\end{tabular}

Values represent means and SD from 5 independent replications; mean values with the same letter in each columns do not differ significantly according to Newman-Keuls test $(p=0.05)$

${ }^{\text {a }}$ Control (distilled water)

${ }^{\mathrm{b}}$ Effectiveness (in brackets)

${ }^{\mathrm{c}}$ Standard copper oxychloride preparation (Miedzian $50 \mathrm{WP}$ ) 
Table 7 Phytotoxicity of phloroglucinol and hydroquinone to 'Idared' blossoms

\begin{tabular}{ll} 
Treatment & $\begin{array}{l}\text { Degree of browning } \\
\text { of flower petals }\end{array}$ \\
\hline Control $^{\mathrm{b}}$ & $0.0 \pm 0.0 \mathrm{a}$ \\
Phloroglucinol $^{\mathrm{c}}$ & \\
$10 \mathrm{mM}$ & $0.3 \pm 0.3 \mathrm{ab}$ \\
$50 \mathrm{mM}$ & $0.5 \pm 0.2 \mathrm{bc}$ \\
$100 \mathrm{mM}$ & $1.2 \pm 0.2 \mathrm{~d}$ \\
$200 \mathrm{mM}$ & $1.9 \pm 0.5 \mathrm{e}$ \\
Hydroquinone & \\
\hline $10 \mathrm{mM}$ & $0.8 \pm 0.5 \mathrm{~cd}$ \\
$50 \mathrm{mM}$ & $2.5 \pm 0.1 \mathrm{f}$ \\
$100 \mathrm{mM}$ & $3.0 \pm 0.5 \mathrm{f}$ \\
$200 \mathrm{mM}$ & $4.0 \pm 0.0 \mathrm{~g}$
\end{tabular}

Values represent means and SD from 5 independent replications; mean values with the same letter in each columns do not differ significantly according to Newman-Keuls test $(p=0.05)$

${ }^{\text {a }}$ Scale: 0- lack of browning of flower petals area, 4- browning of over $50 \%$ of flower petals

${ }^{\mathrm{b}}$ Distilled water

${ }^{\mathrm{c}}$ Aqueous solution

\section{Discussion}

The role of phenolic compounds in Malus - E. amylovora interactions is related to the apple cultivar used, the bacterial strain, the inoculation method, the examined time span after inoculation and the kind of determined phenolics (Cheynier etal. 2013). Roemmelt et al. (1999) found that high contents of phenolic acids in apple leaves were correlated with a restricted disease development. The authors suggested that the accumulation of these compounds create a chemical barrier inhibiting the spread of E. amylovora throughout the cortex tissue of petiole and stem. However, Pontais et al. (2008) and Dugé de Bernonville et al. (2011) proposed that the constitutive phenolics composition of apple cultivars was not associated with susceptibility to fire blight.

In our study, the composition of constitutive soluble phenolics in older (fully expanded) intact leaves of the fire blight resistant and susceptible cultivars showed that the differences between them were not great and limited rather to glucoside forms of selected phenolics. In the highly resistant 'Enterprise', higher levels of glucosides of naringenin, 4-hydroxbenzoic acid and gentisic acid were found than in the highly susceptible 'Idared'. It suggests that the first of these cultivars possesses better reservoir of at least three forms of phenolics which may be quickly converted to their biologically active forms. In the younger leaves, significantly higher amounts of almost all flavonoids (except of hesperidin) were detected in 'Idared' than in 'Enterprise'. Only the amount of SA was significantly lower in this 'Idared' cultivar. Moreover, in the intact young leaves of 'Enterprise' catechin glucoside was at higher level than in 'Idared'. It may be important because shortly ( $6 \mathrm{hpi}$ ) after E. amylovora inoculation in 'Enterprise' significant elevation of the level of naringenin was noted, while in 'Idared' only catechin glucoside level increased. Epicatechin was intensively accumulated in E. amylovora-inoculated mature leaves of pear (Vrancken et al. 2013) and it was suggested to determine the resistance of apple against Diplocarpon mali (Yin et al. 2013).

In our study, in comparison to the respective control (water), following the inoculation, 'Enterprise' response was stronger than that of 'Idared'. In the former the levels of 9 phenolics (naringenin, chlorogenic acid, caffeic acid, p-coumaric acid, gentisinic acid glucoside, 4-hydroxybenzoic acid glucoside, gallic acid, phloretin and rutin) increased while in 'Idared' a rise of only 4 (naringenin glucoside, catechin glucoside, chlorogenic and gallic acids) was detected. The earlier (6 hpi) increase in gallic acid content in the resistant cultivar vs its late (72 hpi) accumulation in the susceptible one could work in favor of resistance against E. amylovora. Moreover, the mechanical injury itself (control) enhanced the levels of 4 phenolics in both cultivars, however to different extent in each of them. Treutter (2001) showed that $p$-coumaric acid was the key substrate in the biosynthetic pathways of phenolics in apple. However, in our study, in comparison to respective control, such situation took place only in 'Idared'. On the contrary, after inoculation the content of $p$-coumaric acid increased only in the 'Enterprise' leaves. Thus, it suggests different regulation of pathways leading to $p$-coumaric acid synthesis and metabolism in each cultivar. Yin et al. (2013) indicated that during Malus - D. mali interaction, in addition to epicatechin and $p$-coumaric acid, gallic acid was another key component of the plant response. It improved disease resistance by limiting the pathogen growth and inducing hypersensitive cell death. We 
suppose that gallic acid might also protect 'Enterprise' against E. amylovora infection as its concentration increased after inoculation. Moreover, this compound highly limited E. amylovora growth in vitro. Therefore, we suppose that this effect resulted rather from its toxicity than from the induction of resistance.

In Rosaceae, the involvement of phenolics in the control of fire blight is species-specific. Gunen et al. (2005) reported that pear cultivars resistant to this disease were characterized by higher content of arbutin (hydroquinone $O-\beta-\mathrm{D}$ glucoside) while the sensitive ones - with the higher level of chlorogenic acid. In the studied apple genotypes, both kinds of phenolics were at the same level in older intact leaves but in younger intact leaves higher concentration in 'Idared' was found. After bacteria inoculation, significant increase in chlorogenic acid was observed only in younger leaves of both cultivars but at a different time points. The earlier increase in 'Enterprise' (6 hpi vs 24 hpi in 'Idared') may be connected with defense process.

Phloridzin was commonly proposed to be involved in disease resistance of apple against various diseases (Mikulic-Petkovśek et al. 2008), but its content does not always correlate with the degree of resistance of different apple cultivars (Pontais et al. 2008; Gosch et al. 2010). We found that phloridzin and phloretin levels in older leaves of the susceptible and resistant apple cultivars were similar, whereas in young ones both compounds were on lower levels in 'Enterprise'. However, following infection phloretin increased only in the resistant cultivar which indicates that not the overall levels of those phenolics but the rate at which phloridzin is transformed is likely to play a role in resistance to fire blight. Phloretin and phloridzin can undergo a peroxidase- and/or polyphenol oxidase-mediated oxidation resulting in $o$-diphenols as well as to formation of toxic and highly reactive $o$-quinones which can react with the $\mathrm{NH}_{2}$ - or $\mathrm{SH}$ - groups of proteins (Gosch et al. 2010). Since all apple cultivars accumulate high amounts of phloridzin, differences in disease resistance could be determined by the speed of the oxidation cascade liberating e.g. phloroglucinol after pathogen attack, rather than the level of phloridzin present in the plant prior to infection. For example, in 'Idared', polyphenol oxidase activity increase occurred only in the late phase of E. amylovora infection (Skłodowska et al. 2011a) and no peroxidase activity changes were found (Skłodowska et al. 2011b), indicating that the enzymemediated production of $o$-quinones could be low. Dugé de Bernonville et al. (2011) showed the ability of
E. amylovora to protect itself against apple secondary metabolites. Both in resistant and susceptible genotypes of apple, phloretin concentrations are bacteriotoxic but E. amylovora can stabilize this compound at sublethal level (Pontais et al. 2008). In our study, after bacterial inoculation the diminution of phloretin level was observed only in 'Idared' when in 'Enterprise' it stayed at the same level or increased (24 hpi). This suggests that bacterial action is effective in case of 'Idared'.

However, some phenolics were not detected in our study. Treutter (2001) suggested that, when using common extraction procedures, in apple some phenolic compounds remain undetected or detected at a very low level because they quickly enter the insoluble pool of phenolics e.g. proanthocyanidins or hydroxycinnamic acids participating in cell wall stiffening. Phenolics composition of leaf extracts depends on the organ age: the youngest leaves accumulate oligomeric flavanols whereas the older ones contain higher levels of epicatechin and chlorogenic acid (Treutter 2001). These differences between younger and mature leaves influence the resistance to fire blight in apple and pear (Cheynier et al. 2013; Vrancken et al. 2013). As reported by Vrancken et al. (2013), in pear, fire blight was more severe in inoculated younger leaves. These authors suggested that it resulted from the fact that epicatechin was more abundant in mature leaves whereas chlorogenic acid was more abundant in immature ones. It was shown that E. amylovora was able to suppress both pathways of SA synthesis at the gene expression level, namely via phenylalanine ammonia lyase (PAL) or chorismate synthase activities (Milčevičová et al. 2010; Khan et al. 2012). Our observations are in consistency with the findings of Milčevičová et al. (2010) who found that uninfected resistant plants had the total SA level 4-5 times higher than the susceptible ones and concluded that in the resistant plants after infection the bacterial spreading was limited by SA level. This suggested that the pathogen can induce a relatively weak signal in plant tissues which contributes to plant defense strategy.

It was postulated that elevated SA content in intact resistant apple leaves create relatively high basic levels of a signal molecule which might be quickly engaged under stress conditions (Milčevičová et al. 2010). After inoculation, in cv. 'Enterprise' accumulation of free SA occurred in two phases (24 and 144 hpi) and correlated with massive gSA synthesis. These changes resemble the two phases of classic oxidative burst in incompatible plant-pathogen interactions (Venisse et al. 2003). In our opinion, the resistance of 'Enterprise' might be related 
to the two-phase accumulation of free SA (Fig. 2). We suggest that the susceptibility of 'Idared' may be related rather to delayed free SA accumulation then to the suppression of its synthesis by the pathogen. Transcriptional data and hormone level measurements indicated that the SA pathway was induced in the susceptible and resistant apple genotypes during infection by E. amylovora (Dugé de Bernonville et al. 2012) but, similarly to our results, the observed SA level was higher in the resistant than in the susceptible cultivars.

In our previous study on the effect of benzothiadiazole $(\mathrm{BTH})$, a functional analogue of SA, the BTH-treated 'Idared' plants appeared more resistant against E. amylovora (Skłodowska et al. 2011a). SA signaling is linked to ROS-mediated signaling and production of $\mathrm{H}_{2} \mathrm{O}_{2}$ which triggers HR (Glazebrook 2005; Iakimova et al. 2013; Sobiczewski et al. 2016). It was proposed that E. amylovora induces plant oxidative burst in order to kill the host cells (Venisse et al. 2002). By detecting gene expression of specific HR associated proteases in E. amylovora inoculated leaves of the resistant and not in the susceptible apple cultivar Iakimova et al. (2013) supported the hypothesis that particular HR-related factors may distinguish the apple resistance to fire blight.

The antioxidative activity of phenolics can contribute to plant resistance during the oxidative burst and the HR (Venisse et al. 2001; Gosch et al. 2010). Dugé de Bernonville et al. (2011) provided evidence for bioactivity of dihydrochalcones - especially phloridzin - as functional antioxidants. Thus, the decrease in the phloretin level in 'Idared' observed in the early phase of infection might lead to higher ROS accumulation and quicker cell death which promoted E. amylovora progression by creating a suitable environment for the bacteria.

The available data show that phenolic metabolism is also involved in apple resistance to E. amylovora (Treutter 2001; Cheynier et al. 2013). In our opinion and the other mentioned studies suggest that most of the phenolic compounds may be important for the effective defense against various pathogenic bacteria including E. amylovora. Together with plant age related physiological and biochemical events the coordination of the action of plant defense processes could affect the susceptibility to E. amylovora. Our data support this supposition showing the activity of 4 phenolics (gallic acid, phloroglucinol, hydroquinone and phloretin) for inhibiting the growth of E. amylovora. Also Roemmelt et al. (1999) demonstrated the inhibition of this pathogen by phenolic compounds in vitro and in cortex tissue of Malus taxa. Similar data were presented by Bell et al. (2002) who established that a number of phenolic compounds detected in Malus spp. are potential suppressors of E. amylovora in vitro. They found that among the tested compounds coumaric acid was the most effective and chlorogenic acid - the least effective. The efficacy varied considerably as a function of the concentration. Our data suggest that 'Enterprise' leaves are better prepared to defend themselves against fire blight than 'Idared' because they have a greater amount of free $\mathrm{SA}$, which is related to the generation of quicker and stronger defense associated signaling. In addition, we show a protective activity of hydroquinone and phloroglucinol against fire blight on pear fruitlets and apple terminal shoots. However, the former appeared to be strongly phytotoxic to apple blossoms. Our study substantiates the suggestion of Zhao and Dixon (2009) that the constitutively present phenolics may influence the defense responses but this effect seems not to be strictly dependent on their total pool but rather on the rate of their release from the inactive forms or on the cellular localization and the translocation between different cell compartments.

Knowledge about the physiological and biochemical processes of the plant in response to E. amylovora infection is important for breeding of resistant cultivars and may have an influence on improving the practices for cultivation of E. amylovora hosts. The here reported work adds more information contributing to better understanding of the role of phenolics in fire blight resistance in pome fruit trees.

Acknowledgements This work was supported by Grant No B1611000000052 of University of Lodz, Poland and partially by a Grant from Polish Ministry of Agriculture and Rural Development in the frame of Multiannual Programme "Actions to improve the competitiveness and innovation in the horticultural sector with regard to quality and food safety and environmental protection", task 2.1, conducted by Research Institute of Horticulture, Skierniewice, Poland.

Compliance with ethical standards All authors are aware with the content of the manuscript and have agreed upon its submission to European Journal Plant Pathology

1) The manuscript has not been published in whole or in part elsewhere 
2) The manuscript is not currently being considered for publication in another journal;

3) The manuscript is not split up into several parts to increase the quantity of submissions;

Conflict of interest The authors declare no conflict of interests.

Open Access This article is distributed under the terms of the Creative Commons Attribution 4.0 International License (http:// creativecommons.org/licenses/by/4.0/), which permits unrestricted use, distribution, and reproduction in any medium, provided you give appropriate credit to the original author(s) and the source, provide a link to the Creative Commons license, and indicate if changes were made.

\section{References}

Bell, A. C., Ranney, T. G., \& Eaker, T. A. (2002). Role of endogenous phenolics in resistance to fire blight among flowering crabapples (Malus spp.) Proceedings of SNA Research Conference, 47, 202-206.

Bonasera, J. M., Kim, J. F., \& Beer, S. V. (2006). PR genes of apple: identification and expression in response to elicitors and inoculation with Erwinia amylovora. BMC Plant Biology, 6, 23-35.

Chang, C. C., Yang, M. H., Wen, H. M., \& Chern, J. C. (2002). Estimation of total flavonoid content in propolis by two complementary colorimetric methods. Journal of Food and Drug Analysis, 10, 178-182.

Cheynier, V., Comte, G., Davies, K. M., Lattanzio, V., \& Martens, S. (2013). Plant phenolics: Recent advances on their biosynthesis, genetics, and ecophysiology. Plant Physiology and Biochemistry, 72, 1-20.

Dao, T. T. H., Linthorst, H. J. M., \& Verpoorte, R. (2011). Chalcone synthase and its functions in plant resistance. Phytochemistry Reviews, 10, 397-412.

Dugé de Bernonville, T., Gaucher, M., Guyot, S., Durel, C. E., Dat, J. F., \& Brisset, M. N. (2011). The constitutive phenolic composition of two Malus domestica genotypes is not responsible for their contrasted susceptibilities to fire blight. Environmental and Experimental Botany, 74, 65-73.

Dugé de Bernonville, T., Gaucher, M., Flors, V., Gaillarda, S., Paulina, J. P., Data, J. F., \& Brisset, M. N. (2012). T3SS-dependent differential modulations of the jasmonic acid pathway in susceptible and resistant genotypes of Malus spp. challenged with Erwinia amylovora. Plant Science, 188-189, 1-9.

Fischer, T. C., Gosch, C., Pfeiffer, J., Thilo, C., Gosch, C., Pfeiffer, J., Halbwirth, H., Halle, C., Stich, K., \& Forkmann, G. (2007). Flavonoid genes of pear (Pyrus communis). Trees Structure and Function, 21, 521-529.

Glazebrook, J. (2005). Contrasting mechanisms of defense against biotrophic and necrotrophic pathogens. Annual Review of Phytopathology, 43, 205-227.
Gosch, C., Halbwirth, H., \& Stich, K. (2010). Phloridzin: biosynthesis, distribution and physiological relevance in plants. Phytochemistry, 71, 838-843.

Gunen, Y., Misirli, A., \& Gulcan, R. (2005). Leaf phenolic content of pear cultivars resistant or susceptible to fire blight. Scientia Horticulturae, 105, 213-221.

Hernández, I., Alegre, L., Van Breusegem, F., \& Munné-Bosch, S. (2009). How relevant are flavonoids as antioxidants in plants? Trends in Plant Science, 14, 125-132.

Iakimova, E. T., Sobiczewski, P., Michalczuk, L., WegrzynowiczLesiak, E., Mikiciński, A., \& Woltering, E. J. (2013). Morphological and biochemical characterization of Erwinia amylovora induced hypersensitive cell death in apple leaves. Plant Physiology and Biochemistry, 63, 292-305.

Jensen, P. J., Halbrendt, N., Fazio, G., Makalowska, I., Altman, N., Praul, C., Maximova, S. N., Ngugi, H. K., Crassweller, R. M., Travis, J. W., \& McNellis, T. W. (2012). Rootstockregulated gene expression patterns associated with fire blight resistance in apple. BMC Genomics, 13, 9.

Khan, M. A., Zhao, Y., \& Korban, S. S. (2012). Molecular mechanisms of pathogenesis and resistance to the bacterial pathogen Erwinia amylovora, causal agent of fire blight disease in Rosaceae. Plant Molecular Biology Reporter, 30, 247-260.

Kumar, D. (2014). Salicylic acid signaling in disease resistance. Plant Science, 228, 127-134.

Markakis, E. A., Tjamos, S. E., Antoniou, P. P., Roussos, P. A., Paplomatas, E. J., \& Tjamos, E. C. (2010). Phenolic responses of resistant and susceptible olive cultivars induced by defoliating and nondefoliating Verticillium dahliae pathotypes. Plant Disease, 94, 1156-1162.

Mikulic-Petkovśek, M., Stampar, F., \& Veberic, R. (2008). Increased phenolic content in apple leaves infected with the apple scrab pathogens. Journal of Plant Pathology, 90, 49-55.

Milčevičová, R., Gosch, C., Halbwirth, H., Stich, K., Hanke, M. V., Peil, A., Flachowsky, H., Rozhon, W., Jonak, C., Oufir, M., \& Hausman, J. F. (2010). Erwinia amylovora-induced defense mechanisms of two apple species that differ in susceptibility to fire blight. Plant Science, 179, 60-67.

Pontais, I., Treutter, D., Paulin, J. P., \& Brisset, M. N. (2008). Erwinia amylovora modifies phenolic profiles of susceptible and resistant apple through its type III secretion system. Physiologia Plantarum, 132, 262-271.

Robert-Seilaniantz, A., Navarro, L., Bari, R., \& Jones, J. D. (2007). Pathological hormone imbalances. Current Opinion in Plant Biology, 10, 372-379.

Roemmelt, S., Plagge, J., Treutter, D., Gutmann, M., Feucht, W., \& Zeller, W. (1999). Defense reaction of apple against fire blight: histological and biochemical studies. Acta Horticulturae, 489, 335-336.

Singleton, V. Z., \& Rossi, J. A. (1965). Colorimetry of total phenolics with phosphomolybdic-phosphotungstic acid reagents. American Journal of Enology and Viticulture, 16, 144-158.

Skłodowska, M., Gajewska, E., Kuźniak, E., Wielanek, M., Mikicinski, A., \& Sobiczewski, P. (2011a). Antioxidant profile and polyphenol oxidase activities in apple leaves after Erwinia amylovora infection and pretreatment with a 
benzothiadiazole-type resistance inducer (BTH). Journal of Phytopathology, 159, 495-504.

Skłodowska, M., Gajewska, E., Kuźniak, E., Wielanek, M., Mikiciński, A., \& Sobiczewski, P. (2011b). Phenolic profile and peroxidase activity in apple leaves after Erwinia amylovora infection and BTH treatment. Acta Horticulturae, 896, 489-494.

Sobiczewski, P., \& Millikan, D. F. (1985). Efficacy of chemicals for control of fire blight (Erwinia amylovora). Fruit Science Reports, 12, 27-34.

Sobiczewski, P., Peil, A., Mikiciński, A., Richter, K., Lewandowski, M., Żurawicz, E., \& Kellerhals, M. (2015). Susceptibility of apple genotypes from European genetic resources to fire blight (Erwinia amylovora). European Journal of Plant Pathology, 141, 51-62.

Sobiczewski, P., Iakimova, E. T., Mikiciński, A., WegrzynowiczLesiak, E., \& Dyki, B. (2016). Necrotrophic behaviour of Erwinia amylovora in apple and tobacco leaf tissue. Plant Pathology. https://doi.org/10.1111/ppa.12631.

Treutter, D. (2001). Biosynthesis of phenolic compounds and its regulation in apple. Plant Growth Regulation, 34, 71-89.

Treutter, D. (2005). Significance of flavonoids in plant resistance and enhancement of their biosynthesis. Plant Biology, 7, 581-591.

Van der Zwet, T., Orolaza-Halbrendt, N., \& Zeller, W. (2012). Fire blight: History, biology and management. St. Paul: APS Press.
Venisse, J. S., Gullner, G., \& Brisset, M. N. (2001). Evidence for the involvement of an oxidative stress in the initiation of infection of pear by Erwinia amylovora. Plant Physiology, 125, 2164-2172.

Venisse, J. S., Malnoy, M., Faize, M., Paulin, J. P., \& Brisset, M. N. (2002). Modulation of defense responses of Malus spp. during compatible and incompatible interactions with Erwinia amylovora. Molecular Plant-Microbe Interactions, 15, 1204-1212.

Venisse, J. S., Barny, M. A., Paulin, J. P., \& Brisset, M. N. (2003). Involvement of three pathogenicity factors of Erwinia amylovora in the oxidative stress associated with compatible interaction in pear. FEBS Letters, 537, 198-202.

Vrancken, K., Holtappels, M., Schoofs, H., Deckers, T., Treutter, D., \& Valcke, R. (2013). Erwinia amylovora affects the phenylpropanoide flavonoid pathway in mature leaves of Pyrus communis cv. Conférence. Plant Physiology and Biochemistry, 72, 134-144.

Wildermuth, M. C., Dewdney, J., Wu, G., \& Ausubel, F. M. (2001). Isochorismate synthase is required to synthesize salicylic acid for plant defence. Nature, 414, 562-565.

Yin, L., Zou, Y., Ke, X., Liang, D., Du, X., Zhao, Y., Zhang, Q., \& Ma, F. (2013). Phenolic responses of resistant and susceptible Malus plants induced by Diplocarpon mali. Scientia Horticulturae, 164, 17-23.

Zhao, J., \& Dixon, R. A. (2009). The 'ins' and 'outs' of flavonoid transport. Trends in Plant Science, 15, 72-80. 